\title{
The Effects of Taxation toward Decision of Transfer Pricing on Multi- National Companies in Indonesia
}

\author{
Hendro Lukman \\ \{hendrol@fe.untar.ac.id\}, University of Tarumaneganara, Jakarta, Indonesia.
}

\section{Haliah}

\{haliah3107@gmail.com\}, Faculty of Economics and Business, Hasanuddin University, Makassar, Indonesia.

\section{Darwis Said}

\{darwissaid@yahoo.com\}, Faculty of Economics and Business, Hasanuddin University, Makassar, Indonesia.

\section{Syarifuddin Rasyid}

\{syariefdin07@gmail.com\}, Faculty of Economics and Business, Hasanuddin University, Makassar, Indonesia.

\begin{abstract}
In globalization today, business is no longer limited by distance, time, and place. In order to maintain growth, multinational companies need to do production efficiency by developing international supply chain. Therefore, companies conduct inhouse production or in other countries that can produce products at cheaper prices than producing in origin country so that they can divert profits or optimize tax benefits. The purpose of this study is to determine the effects of tax rates and tax regulations on ethical behavior as a moderation of transfer pricing decisions carried out by multi-national companies in Indonesia. From 30 multi-national companies in Indonesia used as samples that were processed using Partial Least Square, shows that tax regulations have no negative effect to the management in making the decision of transfer pricing, but tariff and ethics have affect positively, as well as when the tax rule and tax tariff are mediated by ethics.
\end{abstract}

Keywords:

Transfer Pricing, Tax Regualtion, Tax Tariff, Ethics, Indonesia.

Article Received: 18 October 2020, Revised: 3 November 2020, Accepted: 24 December 2020

\section{Introduction}

Economic globalization has entered a new dimension of the world economy and has given a growing impact on international transactions. The characteristics of business in this era give emphasis on the reduction and elimination of global economic barriers [1]. The rapid changes in business scopes require a company to move more quickly and make adjustments to be able to compete domestically and globally. The birth of the General Agreement on Trade and Tariff (GATT) and the World Trade Organization (WTO) has removed obstacles to the movement of goods, services, and capital across the countries. The company not only carries out its operations in the home country, but has expanded to other countries to maximize the potentials of the global market and increase profits.

The conditions of globalization above are widely responded by multinationals (MNCs) with various objectives. Most multi-national companies try to improve efficiency through distribution channels and supply chains internationally. Efficiency in distribution can be done by moving the production process to the marketing area. Economic globalization leads to market development and higher production which has an impact on the level of optimization of production costs and differences in income among the countries involved in generating these costs [2]. As for the production efficiency, it can be done by the international supply chain that supplies parts 
of products from several countries to produce or manufacture products in a country that is considered more favorable. The consideration to perform international supply chain is cost factors, such as cost of production, materials, labor, transport, and other costs. This practice is known as transfer pricing. Transfer prices are the prices of entities carried out by companies for the purpose of gaining their market advantage in the industry or achieving natural growth [3]. Market advantage can be achieved through low raw material costs, acquisitions, development of intellectual property and other intangible assets. However, the implementation of transfer pricing in multinational companies can reduce the income tax revenue of the country of origin.

The beginning of Transfer Pricing practice is the intra-firm transactions involving the sale or transfer of tangible and intangible goods among companies in two or more countries. Multinational transfer pricing concentrates on the price of intra-firm trade [4]. Because of the growing importance and continuous fragmentation of production across countries, it further accelerates the growth of intra-firm trade leading to the transfer pricing on tangible goods as a channel of multi-national companies to shift income to the country with low tax so that the difference in tax tariff generates manipulation of transfer pricing [5].

The strategic objectives of international transfer pricing can be grouped into three categories, namely (1) taxation objectives; (2) internal management oriented goals; and (3) internationalization or operational goals [6]. The positive connotation encourages companies to do "spent efficiency" which provides benefits, power, and welfare [7]. The negative effect is that there are transfer pricing rules that must be implemented, the aim of which is to provide a framework that can generate reasonable and fair profits and taxes, so that the tax costs incurred in inter-company transactions cannot reduce national income tax [8] or become a gap to carry out tax evasion as happened at PT Asian Agris Group palm oil company which was proven to embezzled a tax of Rp 2.25 trillion in 2012 through the transfer pricing scheme [9]. Tax laws are very closely related with legal certainty and administrative efficiency.According to Ernst \& Young survey of 850 companies in 24 countries, $40 \%$ of transfer pricing is the most important tax issue facing their company from other tax issues [10]. The tax rates become a vital component in fulfilling the purpose of transfer pricing, difference in tax tariff between the origine country of the parent company and the country where affiliate is located [11]. Transfer pricing has been and continues to be the vehicle of multi-national companies to maintain their income in lower tax jurisdictions [3]. When tax is one factor of transfer pricing, the decision of transfer pricing will be dealing with the tax rules in a comprehensive manner, not only about the rate.

In running the business, every manager will be faced with ethical behavior. Ethical behavior is not only done on daily activities, but also in decision-making. Friedman stated that business social responsibility is how companies use their resources and engage in activities designed to increase profits and remain in the "rules of the game" [12]. Ethical problems arise only with respect to transfer prices and not to transfer price manipulation [13]. Behavioral conditions on management practices traditionally did not consider ethical factors by managers in making decisions. In the context of business, ethical judgment involves individuals' determination whether the actions are ethical, hereinafter whether they will participate [14]. Thus the ethical factor can be considered as a factor in deciding whether transfer pricing to shift profits, or intrafirm transactions to improve efficiency and increase sales through the international supply chain will be done or not.

The purpose of this study is to find out how regulations and tax rates influence transfer pricing decisions with management ethical considerations in multi-national companies in Indonesia, as well as an input for the directorate general of tax in addressing transfer pricing practices in Indonesia. Therefore, the government must pay attention to 
regulations to protect tax reductions due to transfer pricing practices among multinational companies in Indonesia.

\section{Research Methodology}

The research method in this study is quantitative research that uses primary data. Data is obtained through spread questionnaires to companies in Indonesia located in Jakarta and surrounding areas that conduct transfer pricing. The method of collecting samples using the covineince sample method is the collection of information originating from the selected population because it is able to provide the intended information. The subjects in this study are multi-national companies that carry out the practice of transfer prcing and are willing to provide information. Not all multinational companies that are asked for information on the implementation of transfer pricing fill out or provide information. This is a constraint in data collection in this study. The valid samples were 30 multi-national companies this study.

According to explaination above, the model of this study can be drawn in figure 1 :

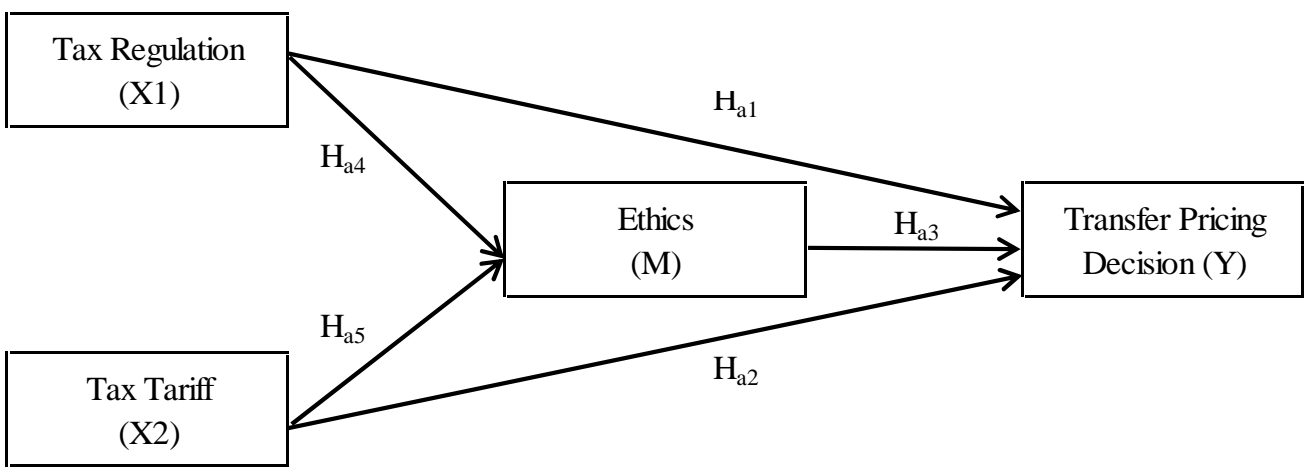

Fig. 1. Hypothesis Model

The 30 data collected ware processed by using Path Least Square (PLS), the reliability, validity data and latent variable correlation were showed as follows:

Table 1. Reliability and Validity Result

\begin{tabular}{lcccc}
\hline \multicolumn{1}{c}{ Variables } & AVE & $\begin{array}{c}\text { Composite } \\
\text { Reliability }\end{array}$ & R Square & $\begin{array}{c}\text { Cronbachs } \\
\text { Alpha }\end{array}$ \\
Ethics & 0.626937 & 0.921152 & 0.62987 & 0.899242 \\
Tax Regulation & 0.541966 & 0.933731 & & 0.928531 \\
Tax Tariff & 0.662421 & 0.946331 & & 0.936079 \\
Transfer Pricing & 0.720608 & 0.885099 & 0.905181 & 0.803343 \\
Decesion & & & & \\
\hline
\end{tabular}

Table 2. Latent Variable Correlation

\begin{tabular}{lcccc}
\hline \multicolumn{1}{c}{ Variables } & Ethics & $\begin{array}{c}\text { Tax } \\
\text { Regualtion }\end{array}$ & Tax Tariff & $\begin{array}{c}\text { Transfer } \\
\text { Pricing } \\
\text { Decision }\end{array}$ \\
Ethics & 1 & & & \\
Tax Regulation & 0.442096 & 1 & & \\
Tax Tariff & 0.771748 & 0.34795 & 1 & 1 \\
Transfer Pricing & 0.914111 & 0.233317 & 0.820099 & 1 \\
\hline
\end{tabular}


Decesion

Based on the data in table 1 above, the value of reliability is greater than 0.7 and the value of Cronbachs Alpha is greater than 0.6, meaning that the data is reliable and valid so that it can be used in this research. This is also supported by the latent variable correlation shown in table 2.

3 Result and Discussion

By using the Partial Least Square, the coefficients of those variables are as follows:

Table 3. Coefficients (Means, STDEV, T-Values)

\begin{tabular}{lccccc} 
& $\begin{array}{c}\text { Original } \\
\text { Sample }\end{array}$ & $\begin{array}{c}\text { Sample } \\
\text { Mean }\end{array}$ & $\begin{array}{c}\text { Standard } \\
\text { Deviation }\end{array}$ & $\begin{array}{c}\text { Standard } \\
\text { Error }\end{array}$ & T-Stat \\
(I0/STE \\
TR to Ethics & 0.197475 & 0.210865 & 0.154429 & 0.154429 & 1.278742 \\
TR to TPD & -0.214716 & -0.197845 & 0.095083 & 0.095083 & 2.258189 \\
TT to Ethic & 0.703037 & 0.689518 & 0.112116 & 0.112116 & 6.270621 \\
TT to TPD & 0.287058 & 0.291731 & 0.127004 & 0.127004 & 2.260238 \\
\hline
\end{tabular}

Legends:TPD=Transfer Pricing Decision,TR=Tax Regulation,TT=Tax Tariff

Table 3 shows that only tax regulation has negative coefficients but has influence on transfer pricing decision in this research. Tax tariff and ethics have direct positive relation and influence to transfer pricing decision. The tax rules and tax tariff influence ethical decisions in determining transfer pricing (63\%, $\mathrm{R}$ in table 1$)$, although the tax rules (1.278742) is not significant to ethics in this research.

Furthermore, analysis of the direct and indirect relationship of tax regulation and tax tariff towards transfer pricing decisions with ethical considerations can be seen in table 4 .

Table 4. Coefficient of Direct - Indirect Effect on Transfer Pricing Decision

\begin{tabular}{lcc}
\hline & Direct toTranfer Pricing & Indirect to Transfer \\
& & Pricing \\
Ethics & 0.787499 & - \\
Tax Regulation & -0.197475 & -0.059204 \\
Tax Tariff & 0.703037 & 0.840699 \\
\hline
\end{tabular}

The coefficient of influence of tax regulation toward transfer pricing decision shows negative direction, even by considering ethical factors, tax regulation still has a negative direction. This means that the tax regualtion is a small factor considered in the transfer pricing decision. Unlike the tax rate, the tax tariff directly has a positive relationship to transfer pricing decision, although considering ethical factor, the tax tariff does not change transfer pricing decision. This happens because the management feels that no ethics have been violated as long as they follow the rules of transfer pricing in countries that have a lower tax tariff to reduce tax obligations and increase company profits. The hypothesis of this study is generally similar to other studies conducted in other countries.

Tax tariff, tax regulation, and ethics directly and partially affect the management to decide to transfer pricing on multi-national companies. These three factors are enough to explain the decision making of transfer pricing, as seen from the magnitude of the value of $\mathrm{R}$ is $91 \%$ (table 1 ). This result is in line with research conducted by Hansen, Crosser \& Laufer which stated that transfer pricing decisions have a significant 
impact on and is influenced by the ethics of the manager to tax evasion [15]. Also tax rules affect managers in making the decision of transfer pricing in accordance with the results of Kim which stated that tax regulations significantly influence transfer pricing decisions [16]. All the factors, ethics shows the most dominant factor in decision making. When Tax Regulation and Tax tariff are mediated by ethics, they also show a significant influence on the decision of transfer pricing. However, the tax rate or tax tariff factor is more prominent than tax regulations.

\section{Conclusion}

The limitations in this study are the difficulty of getting information and the openness of transfer pricing practices in multi-national companies. Furthermore, the principle of taxation in Indonesia applies self-assessment with a $25 \%$ flat tax tariff in 2018, the tax tariff is not competitive compared to other Asean Countries (Thailand 20\%, Singapore 17\%, The philipine 30\%, Myanmar $25 \%$, Laos 24\%, Malaysia 24\%, Cambodia 20\%, Brunei $18.5 \%$ ) and other comptitive industrial countries in Asia such as Taiwan 17\%, Hong Kong $16.5 \%$ ). The difference in tax rates is a prominent determining factor in deciding transfer pricing, so the government needs a policy of decrease tax rates that are more competitive to be able become a destination of multinational companies to conduct intra-firm transactions beside making clear tax regulations to support business without harming or disrupting state budget revenues with strict law enforcement. Currently, several taxation regulations in Indonesia are related to international taxes which directly and indirectly relate to transfer pricing practices. The government through Directorate General of Taxes (DGT) issued regulations relating to transfer pricing such as DGT regulation No. PER-32/PJ/2011 on amendment of DGT regulation No.PER.43/PJ/2010 on the implementation of the Arms Length Principle in transactions between taxpayers and special related parties. Article 1 stated that there must be two parties that should obey the regulation. Article 2 act (2) about limits of the scope of conditions for transfer pricing, stated that the base of transfer pricing can be applied for transactions among taxpayers with special relationship in Indonesia. DGT regulation No. PER-69/PJ/2010 socializes and encourages more taxpayers to implement Advance Price Agreement (APA) [17]. DGT No. PER - 25/PJ/2018, is about Procedures For Applying The Approval Of Avoiding Double Taxation [18] (Directorate General Taxes, 2018), about the procedure of tax treaty, and establishes a Single Document Window [17] with destination countries. Those can reduce or eliminate double tax income and provide rule and legal certainty. Furthermore, there are still other factors that influence the decision of transfer pricing, the accuracy of transfer pricing strategy in saving millions of dollars, but if it goes wrong, it will be a trigger to get a penalty [19] (Tully, 2012). In order to better understand the management behavior of multi-national companies in deciding to do transfer pricing, further research can consider adding non-tax variables as moderating variables such as labor availability, industrial or government regulations, customs regulations, and so on.

\section{References}

[1] Bartelsman, Eric J and, Beetsma, Roel M W J. Why Pay more? Corporte Tax Avoidance Through Transfer in OECD Countires. Tinbergen Institute Discussion PaperNo 00-54/2. June 2000: 1-20 (2000)

[2] Beebeejaun,A. The Efficiency of Transfer Pricing Rules as a Corrective Mechanism of Income Tax Avoidance.Journal of Civil \& Legal Sciences.Journal Civil Legal Science.Volume 7 - Issue 1.A an open access journal ISSN: 2169-0170. DOI: 10.4172/2169-0170.1000237 (2018)

[3] Barker, Joel.,Asare, Kwadwo., and Brickman, Sharon. The Journal of Applied Business Research. Transfer Pricing As A Vehicle In Corporate Tax Avoidance. 
January/February 2017 Volume 33, Number 1 (2017).

[4] Urguindi, J Alfredo. An introduction to Transfer Pricing, New School economics Review. Volume 3 (1), 2008, 27-45 (2008)

[5] Cristea, D Anca, Nguyen, X Daniel. Transfer Pricing by Multi-national Firms: New Evidendence from Foreign Firm Ownership. Social Science Research Network. April 2015 (2015).

[6] Cravens, Karen S. Examining the Role of Transfer .Pricinga as a Strategy for Multinational Firms. International Business Review Vol. 6, No. 2, pp. 127145, 1997 (1997).

[7] Adity, Kukuh Leksono S. Analysis Of Transfer Pricing As A Tax Avoidance And Proposed Suggestion To Prevent Its Disadvantages. Yuridika.Volume 30 No 1, Januari-April 2015 (2015).

[8] Sundoro. Indonesia Tax Law Update Complete Compilation Book1: General Provision and Procedures of Taxation Income Tax.Semar Publishing. Jakarta (2010)

[9] Situmorang, Y. Usut Tuntans Mega skandal Pajak Asian Agri. Https://www.beritasatu.com/nasional/1709 8/usust-tuntas-mega-skandal-ajak-asianagri. download on April 19, 2019 (2014).

[10] McGee, Robert W. Ethical Issues in Transfer Pricing. Manchester Journal of Internati nal Economic Law . Volume 7, Issue 2: 24-41 (2010).

[11] Bradley, Wray. Transfer Pricing : Increasing Tension Between Multinational Firms and Tax Authorities. Accounting \&Taxation.Vol 7 No.2. Pp 6579 (2015).

[12] Friedman, M. The Social responsibility of business is to increase its profits. New York Times Magazine 33, 122-126 (September 13) (1970)

[13] Eden, Lorraine, andSmith, L. Murphy. The Ethics Of Transfer Pricing. For Presentation at the AOS Workshop on
"Fraud in Accounting, Organizations and Society". April 1-2, 2011, Imperial College, London, UK (2013).

[14] Green, Karen. Influence of Ethical Posistion and Information Asymmetry on Transfer Pricing Negotiations, Accounting and Finance Research.Vol 4.No.1 (2015).

[15] Hansen, Don R, Crosser, Rick L, Laufer, Dong. Moral Ethics V. Tax Ethics: The Case of Transfer Pricing Among Multinational s. Journal of Business Ethics. Sep. 1992, 11,9, ProQuest. Pp 679 (1992)

[16] Kim, Yong Gyu. How do Korean Multinational Firms Decide international Transfer Pricing? Journal of Korea Trade.Vol 11. No1. Pp. 173-200. May 2007 (2007)

[17] Huda, Mokhamad Khoirul., Nugraheni,Ninis., and Kamarudin, Kamarudin. The Problem of Transfer Pricing in Indonesia Taxation System. International Journal of Economics and Financial I Vol 7 Issue 4. 2017. 139-143 (2017)

[18] Directorate General Taxes. No. PER 25/PJ/2018, Procedures For Applying The Approval Of Avoiding Double Taxation. The Ministry of Finance (2018).

[19] Tully, Brian. Transfer Pricing Strategies and The Impact on Organization. FinancialExecutive. Jul/Aug 2012; 28,6. ABI/Inform Reserach. 2012. https://www.cnbcindonesia.com/ news/20180304181052-4-6138/tarif-pajaksingapura-dan-11-negara -ini-lebihrendah-dari-as (2012) 